\title{
Children's Right to Family Life in Denmark
}

\author{
Caroline Adolphsen
}

The right to family life is not directly protected in the Danish Constitution, ${ }^{1}$ but involuntary placement of a child into care is considered an intervention in the right to personal liberty under section $71^{2}$

The Constitution thus gives a limited negative protection against interventions by providing a safeguard against removal of the child from the family, but offers no positive right to family life. This right is only granted in the ordinary legislation, namely the Parental Responsibility Act $^{3}$ (governing custody and access), the Social Services Act ${ }^{4}$ (governing interventions in the family and access during a placement of the child outside of his/her home), the Children's Act (establishing who the child's parents are) ${ }^{5}$ and, of course, the law incorporating the European Convention of Human Rights (ECHR) into national law. ${ }^{6}$ As the Convention on the Rights of the Child (CRC), unlike the ECHR, is not incorporated into Danish legislation, the child cannot refer to the convention in order to invoke rights that have no specific basis in the legislation. ${ }^{7}$

It is characteristic for the specific rules that they do not entail a starting point from which the child is capable of exercising his or her individual rights and when the parents exercise the rights. Furthermore, the rules show considerable consideration for the parents' rights to both privacy and family life, even when these rights are in conflict with the wishes and maybe even needs of the child, which can, for instance, be seen in the rules about establishing

1 The Danish Constitution of 5 June 1953 no. 169 (grundloven).

2 See Caroline Adolphsen, 'Constitutional Rights for Danish Children' in Trude Haugli and others (eds), Children's Constitutional Rights in the Nordic Countries (Brill 2019).

3 Parental Responsibility Act of 1 December 2017 no. 1417.

4 Social Services Act of 29 January 2018 no. 102 (Serviceloven).

5 Children's Act of 23 December 2015 no. 1817.

6 Act on Incorporating the European Convention on Human Rights of 19 October 1998 no. $75^{\circ}$.

7 See Adolphsen, 'Constitutional Rights for Danish Children' (n 2 ).

(C) CAROLINE ADOLPHSEN, 2020 | DOI:10.1163/9789004382817_020

This is an open access chapter distributed under the terms of the CC-BY-NC 40akicense. Ado lphsen - 9789004382817 
parenthood and the rules about how to obtain contact between the child and the parent.

On can, of course, only speculate as to whether this unevenness in the regulation is caused by the lack of a specific constitutional protection of the child. As the chapter will show, the child's perspective or best interest and the focus on the child as an individual with an independent right to family life differs in the different sets of rules, making it natural to assume that a constitutional basis for the child's rights would strengthen them or at least force the legislator to make a common legislative ground for children's rights.

The focus of the chapter is parental responsibility, the child's right to contact with his or her family and the rules about public intervention in the child's family. However, as the Danish rules have a very strong focus on the parents as the child's primary family, the rules about establishing paternity or comaternity are also a part of the chapter, as they are very categorical in setting up time limits for paternity or co-maternity cases.

\section{The Right to Know Who Your Parents Are-Regulation of Maternity and Paternity}

\subsection{The Duty of Care and the Importance of Establishing Maternity and Paternity}

It is considered a value in the rules regarding establishing parenthood ${ }^{8}$ that fatherhood and co-motherhood is established so that the child has two parents: both in order to ensure maintenance for the child, but also out of regard for the child's emotional stability and identity creation. ${ }^{9}$ It is furthermore only parents with legal custody who have a duty to care for the child, and the child is, therefore, better protected with two parents than with one.

However, the Danish rules do not guarantee the child two parents even if two people wish to be or become the parents of the child.

According to Danish law, the woman giving birth to the child is the child's mother. ${ }^{10}$ Unless the child is adopted as an infant he/she will always know who the biological mother is and she will play some sort of role in the child's life until the child reaches the age of majority or the mother dies. The mother is

8 The Children's Act chapter $1-5$.

9 Jonna Waage, Børneloven med kommentarer (2nd edn, Jurist- og Økonomforbundets Forlag 2015) 47 .

10 Irene Nørgaard, Caroline Adolphsen and Eva Naur, Familieret (3rd edn, Jurist- og Økonomforbundets Forlag 2017) 24. 
automatically legal custody holder and has the parental responsibility over the child, ${ }^{11}$ making her responsible for providing care for the child.

The child's right to a father or co-mother is not offered the same protection or regard in the legislation.

In order to become a co-parent, be that a co-mother or a father, directly from the birth of the child the mother's partner has to be either married to the mother or live with her in the period of conception and sign a document stating that he/she will care for and be responsible for the child. ${ }^{12}$ If these criteria are not met, the co-maternity or paternity can also be established by the parents signing a declaration or by a district court stating the parenthood pursuant to the rules in the Children's Act.

The Children's Act covers all cases regarding establishing parenthood, but the possibility of appointing a parent who does not meet the criteria mention above is to a wide degree dependent on the mother's and father/co-mothers will to participate.

As long as the woman is still pregnant, the case can only be started by the woman herself and an administrative authority - the latter ensuring the public interest in establishing maintenance for the child (so that society will not have to offer financial support) and the child's interest in knowing who the other parent is. The child's right to two parents independent of the wishes of the mother is, therefore, not activated until the child is born.

After the child is born, both the mother, potential father/co-mother and the legal guardian of the child can start the case. If the legal guardian - in casu the mother - does not make sure that the case is started, the interest of the child is ensured by a specially appointed guardian who can start the case on behalf of the child. ${ }^{13}$ The mother is obliged to disclose who the potential fathers/comothers are, if parenthood has not already been established, ${ }^{14}$ but she cannot be subject to sanctions if she does not, ${ }^{15}$ and the mother and potential

11 Her maternal rights can only be removed by either adoption (termination of the relationship with the child altogether) or by granting the father full custody over the child (which does not terminate her parental rights). If the child is placed into care the mother still holds the legal custody whereas the parental responsibility is largely assigned to the foster-parents or children's home.

12 See the Children's Act chapter 1-1a and the Parental Responsibility Act section 6 and 7. There are several nuances in the rules about periods of separation, couples who are not married when the child is born but get married later on, etc.

13 Under the Guardianship Act of 20 August 2007 no. 1015 section 47.

14 Children's Act section 8.

15 The Administrative Justice Act of 14 November 2018 no. 1284 section 178, subsection 1, no. 1,4 and 5 . 
fathers are encouraged to participate in forensic genetic examinations if it is considered relevant for the case, but cannot be forced to do so. ${ }^{16}$ If the administrative case does not result in the establishment of parenthood, the authority can bring the base before the court, as it is only the court that can establish parenthood if the parties do not come to an agreement in the administrative case. Both the mother and the potential fathers/co-mothers are obliged to appear before the court, but the court cannot use physical force to conduct the forensic genetical examinations. The court can, however, fine the party if he/ she does not show up and/or put him/her in custody until he/she is willing to participate in the court case and give his/her testimony.

\subsection{The Strict Time Limits and R.L. and Others $v$ Denmark}

Though it is considered of great value for the child to know who his/her parents are, the Children's Act entails a strict time limit for starting a paternity/comaternity case. Such a case must be started within six months after the child is born, ${ }^{17}$ and after this fixed limit, the case can only be reopened under very specific circumstances. The short time limit is set out of consideration for the need for stability around the child, ${ }^{18}$ which is interesting as the motivation for establishing the parenthood is (at least partly) the child's right to know who the parents are.

It is also interesting from a child's rights perspective to look at the rules about reopening the case. The case can be opened by the mother, (potential) father/co-mother or by the child or his/her guardian. The law divides the reopening cases into four categories - each with its own criteria:

If no father/co-mother was found in the original case, the case can be reopened without any time limits if it is made probable (antageliggjort) by the applicant that a specific man or woman is the child's parent. In such a situation the child does not risk losing a parent (the person that the child thought was the parent) and the grounds for reopening the case, therefore, do not have to be as heavy as if somebody had been appointed as or considered to be the child's parent earlier on. If the adult child opposes the reopening of the case, it cannot be reopened. ${ }^{19}$

If the parenthood has been established, the case can be reopened if both parents and the child agree and it is made likely (sandsynliggjort) that a specific

16 Children's Act section 11.

17 Children's Act sections 5, 6 and 6 a.

18 Waage (n 9) 121.

19 Children's Act section 21. 
man or woman is the child's parent instead. As it shows, it is harder to reopen such a case than a case where no parent was originally found/pointed out. ${ }^{20}$

If mistakes were made in the original case and the mistakes could have influence on the original result, the case can be reopened within three years after the birth of the child unless the request is made by a party who was aware of or had reason to assume that a mistake had been made, and (for the father/comother) who nonetheless treated the child as his/her own. ${ }^{21}$

If it can be assumed due to new information that the new case will have a different outcome or there are other reasons for assuming this, the case can be reopened even though the parenthood has been established. Just like above the request has to be made within three years after the birth of the child, and just like above, it can be made later if there are very special reasons for the delay and it is not of substantial inconvenience for the child. In these cases, the request must be evaluated in light of the time passed, how the parents have behaved towards the child if they were in doubt of the parenthood, if the request has been made within a reasonable timeframe and whether or not it is likely that the child will have a (new) parent as a result of the case. ${ }^{22}$

The reopening rules, more specifically the latter, were brought before the European Court of Human Rights (ECtHR) in the case of R.L and Othersv. Denmark. ${ }^{23}$ There was no doubt that the registered father was not the father as both parents explained that they had not had sexual relations at the time of conception - at least of the second child. The mother had had an affair during the years where the children were born, but the man she had an affair with was not willing to have the case reopened although there were strong indications that he was indeed the father. Both legal parents wanted the case reopened but the request was denied by the district court because they had both been aware of the strong likelihood that the father was not the biological father but had nonetheless acted as though he was.

The applicants argued that the refusal to reopen the case was a breach of their rights under Article 8. The Court, however, found that the High Court had indeed taken the various interests in the case into account and given weight to what it believed to be the best interests of the children, and notably their interest in maintaining the family united. ${ }^{24}$ The first applicant in

\footnotetext{
20 Children's Act section 22. See Waage (n 9) 282-283.

21 Children's Act sections 23 and 25.

22 Children's Act sections 45 and 25.

23 R.L and Others $v$ Denmark App no. 52629/11 (ECtHR 7 March 2017).

24 R.L and Others $v$ Denmark (n 23) para 47.
} 
the case (the mother) had argued that it would be in the best interest of the children to find their true identity, but both the children's counsel (the competent authority) and the High Court saw it differently, and the ECtHR did not find sufficient reason to set aside this assessment. ${ }^{25}$ When reading the case, it is rather clear that it is important that the mother was aware of the facts all along and did nothing to change the situation for the children who were around four years old and two years old when the case started, and that the assessment might have been different, had the request been made by the children. The ECtHR explicitly says: 'The Court cannot ignore, either, that the first applicant, being the best placed person to know about any uncertainty as to the fatherhood of her children, did not take any initiative to establish their biological identity until 29 November $2008 .{ }^{26}$ Or to put it differently: As the mother was both responsible for and aware of the situation, no special considerations were to be made on her behalf. As a conclusion, one could say that the ECtHR accepts the strict reopening rules as long as there is still room for discretion.

\subsection{The Two-Parent Principle and the Best Interest of the Child}

The emergence of new family structures challenges the notion of the family as consisting of two parents and children. This has not yet resulted in a legislative discussion or initiatives towards accepting a larger number of parents. Here, in $2018 / 2019$, there is an ongoing legislative process towards great changes in the family-related legislation, which has just resulted in a new administrative system, ${ }^{27}$ but the rules do not change the two-parent principle and no suggestions have been made to widen the number of parents, for instance, in cases where a couple have a child with a known donor.

\subsection{Conclusion}

The child's right to know who his or her parents are is limited by a number of procedural rules and strict statutes of limitation protecting the potential parent's right to privacy. One could certainly argue that a best interest-approach in the constitution would encourage the legislator to consider whether the rules should be changed.

\footnotetext{
$25 \quad$ R.L and Others $v$ Denmark (n 23) para 48.

$26 \quad$ R.L and Others $v$ Denmark (n 23) para 48.

27 The Familiehouse Act of 27. December 2017 no. 1702.
} 


\section{The Right to Contact with the Non-Cohabitant Parent and the Rest of the Family}

\section{1}

\section{The Parental Responsibility Act and the Best Interest of the Child}

The Parental Responsibility Act puts forward a rights-based approach for the child in cases regarding contact to the non-cohabitant parent and thus introduced - at least on paper - a paradigm shift in the thinking behind the rules. The child - not the parent - has a right to contact and the decision regarding access has to be in the best interest of the child. ${ }^{28}$ However, even though the child's perspective has to be part of the basis for the decision, the child itself is not a party to the case and cannot start a case regarding access or complain about a decision on the matter. To remedy the lack of rights for the child, the law grants children above the age of ten the right to ask the competent body to call the parents to a meeting regarding (among other things) the question about contact. ${ }^{29}$ However, the parents are not obliged to participate in the meeting and the competent authority has no ex officio powers to start a case based on the child's wishes. The child, therefore, has no actual legal remedies and can be said to be totally reliant on the parents starting the case.

The rules are a clear example of the fundamental understanding in Danish law that the parents want what is best for their children, and know what is best for their children. If the parents reach an agreement, the decision is as a clear main rule considered to be in the best interest of the child and the only safeguard is the duty to report to social services for the caseworker who has to register the parents' agreement, if they chose to have it registered, which is necessary if it is to serve as a basis for enforcement of the agreement at a later point. It is thus not a prerequisite that the agreement is registered and it is not a part of the registration that the caseworker makes a discretion of whether or not the agreement is in the best interest of the child. If the parents do not agree, they can start an access case.

\subsection{Access Cases - a Parent's Right to Contact with the Child}

Though the Parental Responsibility Act talks about the child's right to access, it is not up to the child to start an access case, and the parent cannot be forced to have contact with the child if the parent does not want it. ${ }^{30}$ The 'right' to

28 The Parental Responsibility Act section 19, subsection 1.

29 The Parental Responsibility Act section 35.

30 In the preparatory works it is thus stated that the wording (the child's right to access) is of moral/political nature. See квет 2006/1475 'Barnets Perspektiv: forældremyndighed, barnets bopæl, samvær, tvangsfuldbyrdelse: betænkning afgivet af Udvalget om 
access thus only actually counts if the parents agree on access or the parent in question is interested in access and is willing to start a case.

The preparatory works discussed whether or not the child should have full rights as an independent party in cases regarding access, custody and residence. But it was concluded that it would not be in the best interest of the child to commence actions against the parents ${ }^{31}$ - in these cases, the best interest of the child is a protection from having to take action on his/her own. ${ }^{32}$

The other underlying best interest-assumption in the law is the main rule that it is beneficial for children to have contact with both parents. ${ }^{33}$ It means that there will be established contact between the parent and the child if the parent applies for it. This main rule has been criticised for giving the noncohabitant parent (typically the father) rights on behalf of the child. It has been further strengthened by the fact that the child cannot itself choose not to have contact and by the fact that a decision about access can be executed with the use of force unless the child's physical or mental health is exposed to serious risk. ${ }^{34}$

As one of the reasons not to grant access, however, is a high-level of conflict between the parents, ${ }^{35}$ other stakeholders have criticised the law for making it possible for the cohabitant parent to prevent access by starting and maintaining conflicts that influence the child in a negative way making it unadvisable from a best-interest perspective to grant access.

The rules have been changed a number of times during the 11 years that the law has been into force, and it seems difficult for the legislator to strike the best balance between the best interest of the child and the right to family life and privacy under article 8 of the European Convention on Human Rights. The shift in the wording has apparently not made it easier to ensure that the main focus is indeed the child. ${ }^{36}$

Forældremyndighed og Samvær', 2.3.2. See also Stine Krone Christensen, Forceldreansvarsloven med kommentarer (2nd edn, Karnov Group 2014) 301.

31 See квет 2006/1475 'Barnets Perspektiv: forældremyndighed, barnets bopæl, samvær, tvangsfuldbyrdelse: betænkning afgivet af Udvalget om Forældremyndighed og Samvær', 4.6.3.1.

32 See about this reasoning in Stine Jørgensen, 'Børns rettigheder i socialretlige og familieretlige sager' (2007) 4 Tidsskrift for Familie og Arveret 525 .

33 See Lovforslag L 133, 2006-2007, the specific remarks to § 4; Stine Krone Christensen, Forceldreansvarsloven med kommentarer (2nd edn, Karnov Group 2014) 98.

34 The Administration of Justice Act of 22 September 2017 no. 1101 (Retsplejeloven) section 536 , subsection 6 .

35 See the administrative guidelines for cases regarding access, 'Vejledning nr. 11362 af 30 December 2015', section 14.1.1.2., Samvær.

36 The Parental Responsibility Act sections 20 and 22. 


\subsection{Access to the Extended Family}

As mentioned above, the rules regarding parenthood only allow for the child to have two parents. This view is mirrored in the rules regarding access as the possibility for the child to maintain contact to the extended family or siblings is very narrow. These rules thus only apply if one or both of the parents are dead, one of the parents is unknown or under very limited circumstances if both parents are known and alive but the child only has very little or no contact to one of the parents. ${ }^{37}$

Furthermore, the rules only regard the child's closest next of kin and as mentioned before the child himself/herself cannot start the case if he/she would rather have contact to someone else - cases can only be started by the adults seeking contact. The concept of who the child's family is can therefore be said to be defined by the legislator instead of asking the child. A relevant example where the child is left without rights would be if the child wants to have a right to stay in contact with his/her former stepsiblings but without the parents' acceptance. The problem is somewhat remedied for older children who can maintain contact online but from a rights-based approach this somewhat coincidental solution outside of the rules is not satisfactory for the child.

\subsection{Access When the Child is Placed into Care}

When a child is placed into care in Denmark, legal custody remains with the custody holding parent(s) and the child is still considered a part of the biological family. The child has a right to stay in contact with the biological family during the placement.

The issue is governed by the Social Services Act and unlike the cases governed by the Parental Responsibility Act, where the child is living with one of the parents, the access rule for children placed in care gives a right to stay in contact not only with the child's parents but also with the child's network. ${ }^{38}$ The difference between the two sets of rules can be explained by the fact that whereas contact cases can involve parents who have sufficient parental abilities there is presumably a greater need for support from the network for children who are placed into care and a need for their support after a placement is terminated. ${ }^{39}$

37 The Parental Responsibility Act sections 20 and 22.

38 The Social Services Act section 71, subsection 1.

39 This is also reflected in section 47 that imposes a duty on the responsible authority to consider how to involve the child's network in any social welfare case. See Trine Schultz and others, Socialret: Børn og Unge (Jurist- og Økonomforbundets Forlag 2017) 366. 
The application for access, however, must still be given by one of the parents, and neither the parents nor other members of the network are obliged to visit or in other ways have contact to the child. Children aged 12 years and above can complain about a decision about access but this presupposes that one of the parents actually starts a case.

If access is not granted at all or if the visits are limited to less than once a month, the decision cannot be made by social services. It has to be put before the same board that can decide to remove the child from his/her home and place him/her into care, and the same legal rights and procedures are set into motion. ${ }^{40}$

\subsection{Conclusions and Reflections}

Though the rules about contact between the child and family clearly state that their focus is solely on the child's right to contact, this is not the case when it comes to actually ensuring the right. To change this it would, as the Danish administrative and legal system is constructed, be necessary to give the child a number of independent rights - as a party to his/her case - as done in the Social Services Act. ${ }^{41}$ This does not require an amendment to the Constitution, and it is my opinion primarily a matter of the underlying assumption in the Parental Responsibility Act that the parent(s), as a minimum rule, act in the best interest of their child.

Intervention in the Child's Right to Family Life

\section{1}

\section{Placement of the Child Outside of His/Her Home}

4.1.1

Consent from the Child or the Parent?

The consent of a child below the age of 15 is not necessary to deem a placement by social welfare authorities of the child outside of his/her home voluntary or to consider a placement in a psychiatric ward voluntary. ${ }^{42}$ If the custody holder(s) gives consent, the placement is not considered an intervention in the right to personal liberty for the child and the decision can be, therefore, made by the caseworker her/himself and there is no access to a special judicial control of the placement for the child.

The child can complain about a placement in foster care or another social welfare institution from age 12 but only to an administrative board, and the child

\footnotetext{
40 The Social Services Act section 73, subsections 3-4.

41 See directly below.

42 See Adolphsen, 'Constitutional Rights for Danish Children' (n 3), section 4.2.
} 
has no clear legal basis for complaining about a hospitalization in a psychiatric ward. If the parent does not consent to a placement in either a social welfare institution or a psychiatric ward, however, the child has a right to a lawyer from age 12 and can request that the case undergoes the special judicial control. ${ }^{43}$

As shown, the limitation of the child's liberty is considered less serious if the parents give consent. This is because the intervention has traditionally been seen as an intervention in the parent's rights. One could, therefore, argue that the rules do not pay sufficient attention to the family life between siblings or the child's family life with other relatives. As mentioned above, this is, interestingly enough, mirrored in the rules about access once the child is already in care, which apply in both cases about placement with or without consent from the parent.

\subsubsection{The Involuntary Care-Case}

If the custody holder or the child above the age of 15 do not consent to the placement and the placement is deemed necessary under the specific criteria in the Social Services Act, the local authority has to bring the question about placement before a local administrative board with both legal, psychological and pedagogical expertise. ${ }^{44}$

The cases are handled in a quasi-judicial setting and both the parents and the child above the age of 12 are issued an attorney and have a right to appear before the board. ${ }^{45}$ The law also specifically states that the parties must be given explicit information about the right to document access - although the extent of the right is the same as in other cases.

If the administrative board decides that the criteria for involuntary placement are met, the parents and the child aged 12 and above have the right to bring the case before a court under the special and comprehensive rules in the Administration of Justice Act. ${ }^{46}$

If the decision is upheld, the child is placed into care in principle under the same rules that govern voluntary placements. ${ }^{47}$ In both cases, the child can end up in a 'continued placement', i.e. a more permanent placement - possibly up until the child turns 18 - if the municipal authority in charge of social welfare

43 See Adolphsen, 'Constitutional Rights for Danish Children' (n 3), section 4.2.

44 The rules about the competent body, 'Børn og ungeudvalget', are found in the Act on due process and administration in social law cases of 8 March 2018 no.188.

45 The Social Services Act section 72, subsection 1, no. 2 and section 74, subsection 1, no 2 and subsection 2. If the child is below the age of 12 he/she also has a right to appear before the board but only if is not harmful for the child.

46 Chapter 43 a.

47 See specifically section 70 , subsection 1 about revision of the plans for the placement and the overall placement decision, but it is possible for the administrative board to make a 
cases finds it necessary and the criteria for the continued placement are met. This means that the case worker on the basis of her professional discretion and initiative, can recommend to the administrative board mentioned above that they make a decision on continues placement if the child has been placed in care for three years if the child has developed such a powerful connection to the care facility that it - either in the shorter or longer run - is considered to be of significant importance for the best interest of the child to remain at the facility. The decision can be made even if the grounds for the decision of placing the child in care in the first place are no longer present. ${ }^{48}$ This is in contrast to the principle of proportionality in the Social Services Act stating that interventions cannot continue longer than required, that is to say longer than the grounds for the interventions are present and is an example of rules given more weight to the best interest of the child than to the legal certainty of the parents.

Since the criteria is the best interest of the child, it is interesting that the rule states that only the child above the age of 15 has to give consent to the placement. The age-limit is coherent with the age-limit for voluntary placement and, therefore, appears to make sense, but why insist upon having the opportunity for continued placement without consent from the child, when the child is already protected by the 'normal' placement? As continued placement builds on the child's right to stability it is difficult to argue that such a placement would be in the best interest of the child who does not want to stay at the foster-home bearing in mind that it is only necessary to make the decision if the grounds for the placement are no longer present.

\subsection{Adoption without Consent}

The Danish rules about adoption without consent were changed in 2009 and 2015 in order to make it easier to terminate the relationship between the child and parents. ${ }^{49}$ The criteria for the decisions have therefore been widened, and more focus has been put on the child's emotional attachment to the foster family or care facility where the child lives and less on the parent's (lack of) parental abilities. Before 2015, adoption without consent could not be granted if the parent had parental abilities but now it is sufficient that the criteria for an involuntary placement are met and that it would be harmful for the child

decision about prolonging the deadline for revision of the placement under the specific rules in section 62 .

48 The Social Services Act section 68 a.

49 See LFF nr. 105 of 28 January 2009 (from now on LFF nr. 105), the specific remarks to $§ 1$, nr. 6. See Caroline Adolphsen, 'Tvangsadoption af anbragte børn' (2015) 48 Ugeskrift for Retsvæsen 45o. 
to discontinue the contact with the foster-parents due to the closeness of the foster-parent/child-relationship. ${ }^{50}$ Whether or not this is a positive thing depends on one's view of the rights of the biological family when these are in conflict with the rights of the child, but the rules have been criticised for leaving the parents with insufficient legal certainty. ${ }^{51}$

As adoption means that the family life between the parent and the child as a clear main rule ceases to exist, ${ }^{52}$ the procedure for the decision is very comprehensive and involves both municipal (kommunale) and national authorities, access to the same court procedure as in involuntary placement cases and unlike placement cases - a delayed effect of the administrative case if the parties bring it before court.

However, it is quite clear from reading the rules, the preparatory works and the spars case-law that the child has a very passive role in the procedure compared to placement cases. The adoption rules ${ }^{53}$ do not have an age-limit for consent from the child, but only a right to be heard and a rule stating that if the child is aged 12 and above the authorisation 'should not' be given without consent from the child unless it is considered to be damaging for the child to be asked for consent. ${ }^{54}$ The consent is thus not a prerequisite for the decision, and it does not change the procedure that the child opposes the adoption.

\subsection{Comments and Perspectives}

In cases regarding interventions in the right to family life, it is quite clear that the lack of a specific constitutional protection of the child has a direct impact on the child's rights in the legislation. By implementing such a right in the Constitution for the child regardless of his/her age the constitutional assembly could impose a specific duty on the legislator to make the rules more discretion-based and less dependent on age-limits. ${ }^{55}$ As age-limits, however, also exist in the other Scandinavian countries where the child does have independent and specific rights in the Constitution, it would, however, be necessary with very clear constitutional rules if there were to be perceived as boundaries on the legislator.

50 The Adoption Act of 3 March 2018 no. 1041 section 9, subsection 4.

51 See Mads Pedersen, 'Forældre med handicap og tvangsadoption' (2016) 8 Ugeskrift for Retsvæsen 99; Caroline Adolphsen, 'Tvangsadoption af anbragte børn' (2015) 48 Ugeskrift for Retsvæsen 45o. Mads Pedersen was at that point employed at the Danish Institute on Human Rights.

52 There is a very narrow opportunity for contact after the adoption in PRA section 20 a, but this is in no way as strong a right as in ordinary access cases.

53 The Adoption Act (n 5o).

54 The Adoption Act section 8.

55 See, for instance, the Norwegian Barnevernloven § 4-4a, stk. 1, litra d. 


\section{$5 \quad$ Concluding Remarks}

As shown above, the child's right to family life is protected in a number of different sets of rules and the rules do not contain a uniform approach to independent rights for children. The Constitution only projects the child from being removed from the family and offers no positive rights to family life or contact. There is no political desire to change the Constitution and as the political agenda in Denmark is to challenge the international human rights instead of adoption them, ${ }^{56}$ no such desire will probably arise in the foreseeable future. Though all of the rules have been changed several times in the last years, no attempts have been made to make a common ground for children's rights. Whether such a common ground - for instance, regarding age limits - is desirable is a matter for the legislators, but from a legal perspective, it is interesting that the differences seem more coincidental and based on historical grounds than a well-thought-out view on the child's rights.

\section{References}

Adolphsen C, 'Constitutional Rights for Danish Children' in Trude Haugli and others (eds), Children's Constitutional Rights in the Nordic Countries (Brill 2019).

Adolphsen C, 'Tvangsadoption af anbragte børn' (2015) 48 Ugeskrift for Retsvæsen 450. Christensen SK, Forceldreansvarsloven med kommentarer (2nd edn, Karnov Group 2014). Jørgensen S, 'Børns rettigheder i socialretlige og familieretlige sager' (2007) 4 Tidsskrift for Familie og Arveret 523 .

Nørgaard I, Adolphsen C and Naur E, Familieret (3rd edn, Jurist- og Økonomforbundets Forlag 2017).

Pedersen M, 'Forældre med handicap og tvangsadoption' (2016) 8 Ugeskrift for Retsvæsen 99 .

Schultz T, Socialret: Børn og Unge (Jurist- og Økonomforbundets Forlag 2017).

Waage J, Børneloven med kommentarer (2nd edn, Jurist- og Økonomforbundets Forlag 2015).

56 This has been explicitly stated by several ministers in the current government, see, for example, <https://www.dr.dk/nyheder/politik/stoejberg-i-muligt-konventionsbrud-jeggoer-det-med-aabne-oejne $>$ (the Minister of Immigration and Integration) or $<$ https:// www.dr.dk/nyheder/politik/pape-i-spidsen-reform-af-domstol-menneskerettigheder-erikke-uroerlige> (the Minister of Justice) accessed 10 January 2018. 
Caroline Adolphsen - 9789004382817 Downloaded from Brill. com $04 / 26 / 2023$ 03:12: 03PM via free access 